\title{
Elastography in Breast Imaging
}

\author{
Elastografie in der Brustbildgebung
}

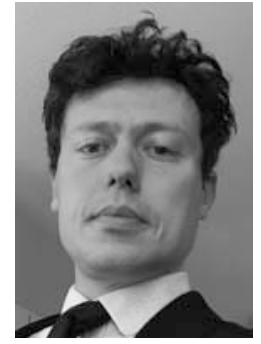

Jonathan Frederik Carlsen

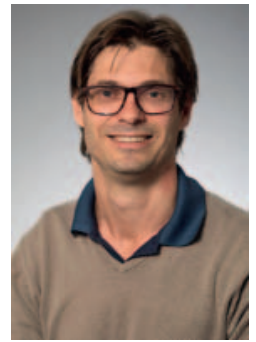

Kristoffer Lindskov Hansen

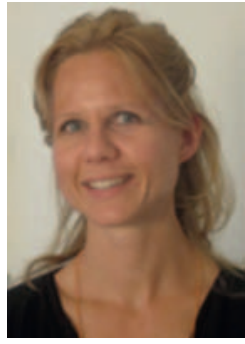

Caroline Ewertsen

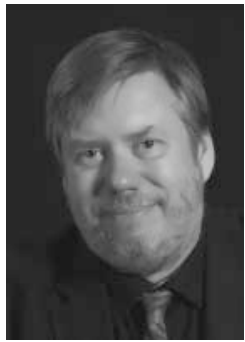

Michael Bachmann Nielsen

\author{
Correspondence \\ Prof. Michael Bachmann Nielsen \\ Dept. of Radiology, Rigshospitalet \\ DK 2100 Copenhagen, Denmark \\ mbn@dadlnet.dk
}

Bibliography

DOI https://doi.org/10.1055/a-1022-7326

Published online: 2019

Ultraschall in Med 2019; 40: 688-691

(c) Georg Thieme Verlag KG, Stuttgart · New York

ISSN 0172-4614
Elastography has been one of the most intensely investigated additions to clinical ultrasound examinations for almost two decades. Elastography guidelines for many different anatomical regions have been published by different medical scientific societies [1-5]. In general, two different methods of elastography are available - strain (SE) and shear wave elastography (SWE) [6, 7]. Shear wave elastography has been most extensively researched for liver applications, but within recent years the method has also been evaluated for focal lesions in the breast, the thyroid and other organs. In shear wave elastography, the speed of shear waves, which arise perpendicularly to a push pulse from the transducer, is measured. In strain elastography, mechanical stress is applied to the transducer, and the deformation of tissue is shown on a color map, which may be interpreted visually or semi-quantitatively calculating a ratio. This method is mainly used for the evaluation of focal lesions.

One of the first and most widely examined clinical applications for ultrasound elastography was the evaluation of breast tumors. In breast elastography, the evaluation of the strain images may be performed qualitatively or semi-quantitatively. The qualitative method uses the Tsukuba score with 5 categories, where an increasing number indicates an increased risk of malignancy [8]. The semi-quantitative measure is based on calculating a strain ratio, which is the deformation of a lesion relative to the surrounding tissue [9]. Several groups have tried to establish a cut-off for strain ratios to separate benign and malignant lesions, but without reaching consensus. Recent research has indicated that strain elastography may play a role mainly in distinguishing BIRADS 3 and 4 lesions $[10,11]$.

Early studies of ultrasound elastography focused on the feasibility of the different techniques and the comparison of elastography compared to B-mode ultrasound as a stand-alone examination [8, 12-14]. Most studies found, that elastography could not replace the $\mathrm{B}$-mode examination, although specificity tended to be higher than for B-mode examinations as also demonstrated by a recent article in EJU [15]. Later, the combination of ultrasound elastography with the conventional B-mode examination was the primary focus of several studies, generally showing convincing results $[11,16]$. In accordance with this, the latest edition of the BI-RADS classification system incorporated ultrasound elastography, either SE or SWE, as one of the associated features to assess the risk of malignancy [17].

More recently the focus of the diagnostic work-up of breast tumors with elastography has been centered on the evaluation of the difficult intermediate-risk BI-RADS classes, namely BI-RADS 3 and $4 a$, as was the case with a recent article published here in EJU [10]. In this study of more than 1000 breast tumors the pre-test probability of breast cancer of $1.3 \%$ for BI-RADS 3, was improved to a post-test probability of 29.8 after using strain ratio calculation. Likewise, for BI-RADS 4 the pre-test probability of breast cancer was improved from $8.5 \%$ to a post-test probability of $48.7 \%$ following strain ratio calculation. In another study using both strain- and shear-wave imaging, 290 out of 494 BI-RADS 4a tumors were downgraded to BI-RADS 3 with only one malignant lesion incorrectly downgraded [18]. A study using known breast 
cancer risk factors to stratify women with BI-RADS class 4a in to average risk and high risk patients, strain elastography could additionally subdivide the former group in to a soft and non-soft tumor group with only $1.5 \%$ malignancies in the soft tumor group, making the frequency of malignancies comparable with BI-RADS 3 tumors [19]. In another large study, SWE was used to both upgrade BI-RADS 3 and downgrade BI-RADS 4a tumors thereby improving the overall specificity of the examination without lowering sensitivity [11]. Both EFSUMB and WFUMB guidelines for ultrasound elastography encourage the addition of elastography to the B-mode examination of breast tumors and agree, that elastography could be used to upgrade stiff BI-RADS class 3 lesion for immediate biopsy [1, 20].

Most recently the focus of several research publications has been the evaluation of breast tumor response to neoadjuvant chemotherapy using ultrasound elastography. In one recent article here in EJU 3D shear-wave elastography was shown to be a feasible imaging modality to evaluate volumetric changes in breast tumors following neoadjuvant chemotherapy, while an article published last year showed conventional 2D shear-wave elastography to be able to better predict pathological complete response to neoadjuvant chemotherapy after three cycles of treatment than both conventional US and MRI [21, 22]. These results have been substantiated by articles showing that strain elastography can predict pathological complete response after two weeks of chemotherapy treatment and that results may further be improved when combining elastography with contrast-enhanced ultrasound [23-25].

3D SWE has also been used for tumor size assessment in breast cancer in a recent study [26]. When compared to 2D SWE, strain elastography and B-mode ultrasound, conventional B-mode imaging was superior, although 3D SWE was more accurate than 2D SWE and SE for the subgroup of invasive ductal carcinoma.

To automate elastography exams, computer-aided tools have been evaluated, and a study using texture analysis in SWE for tumor classification showed improvements of specificity, sensitivity, and accuracy when compared to conventional SWE evaluation [27]. In another study evaluating real-time strain elastography (SE), a method was devised to calculate four SE features improving specificity from $54.5 \%$ to $95.2 \%$ when B-mode US was combined with computer-aided SE [28].

In these years artificial intelligence ( $\mathrm{Al}$ ) has gained much attention in medical science, and breast imaging is one of the focus areas [29]. New use of elastography has been proposed for segmentation, which is a crucial step for Al performance. An algorithm for automatic segmentation of breast tumors was proposed by fusing B-mode, Power Doppler and SWE elastography images [30]. In a retrospective study, SWE and B-mode images were segmented and analyzed, and data were fed into an algorithm for learning and classification. The study showed sensitivity, specificity, and accuracy of $97.8 \%, 94.1 \%$, and $95.6 \%$, and could potentially become a non-invasive tool for diagnosis avoiding unnecessary biopsies [27].

Elastography has become a useful tool in the work-up of breast imaging and tumor assessment and is becoming an integrated part of the breast examination. With the arrival of 3D elastography, and computer-aided tools and Al designed for elastography, new possibilities will emerge, which further will enhance the use of this powerful ultrasound technique.

\section{Elastografie in der Brustbildgebung}

Die Elastografie ist seit fast zwei Jahrzehnten eine der am intensivsten untersuchten additiven Verfahren zu klinischen Ultraschalluntersuchungen. Richtlinien zur Elastografie vieler unterschiedlicher anatomischer Regionen wurden von verschiedenen medizinischen Fachgesellschaften veröffentlicht [1-5]. Im Allgemeinen stehen zwei elastografische Verfahren zur Verfügung, Strain-Elastografie (SE) und Scherwellen-Elastografie (SWE) [6, 7]. Die Scherwellen-Elastografie wurde am intensivsten bei Leberanwendungen erforscht, aber in den letzten Jahren wurde diese Methode auch für fokale Läsionen der Mamma, Schilddrüse und anderer Organe evaluiert. In der Scherwellen-Elastografie wird die Geschwindigkeit von Scherwellen gemessen, die durch Druckimpuls senkrecht aus dem Schallwandler entstehen. In der StrainElastografie wird durch den Schallwandler mechanisch Druck ausgeübt und die Verformung des Gewebes wird auf einer Farbkarte dargestellt, die visuell oder semi-quantitativ durch Bildung einer Ratio interpretiert werden kann. Diese Methode wird hauptsächlich zur Beurteilung von fokalen Läsionen eingesetzt.

Eine der ersten und am weitesten verbreiteten klinischen Anwendungen für die Ultraschall-Elastografie war die Untersuchung von Mammakarzinomen. In der Brust-Elastografie kann die Auswertung der Strain-Bilder qualitativ oder semi-quantitativ erfolgen. Die qualitative Methode verwendet den Tsukuba-Score mit 5 Kategorien, wobei mit zunehmendem Score ein steigendes Risiko für Malignität angezeigt wird [8]. Die semi-quantitative Messung basiert auf der Bildung der Strainratio, welche die Verformung einer Läsion im Verhältnis zum umgebenden Gewebe angibt. Mehrere Forschergruppen haben versucht, einen Cut-offWert für die Strainratio zur Differenzierung von gutartigen und malignen Läsionen zu etablieren, ohne jedoch einen Konsens zu erzielen. Neuere Forschungen haben gezeigt, dass die StrainElastografie vor allem bei der Unterscheidung von BI-RADS 3 und 4 Läsionen eine Rolle spielen kann [10, 11].

Erste Studien zur Ultraschall-Elastografie konzentrierten sich auf die Durchführbarkeit der verschiedenen Methoden und die Elastografie als eigenständige Untersuchung im Vergleich zum B-Mode-Ultraschall [8, 12-14]. Die meisten Studien fanden heraus, dass die Elastografie eine B-Mode Untersuchung nicht ersetzen konnte, obwohl die Spezifität tendenziell höher war als im B-Mode, wie auch ein aktueller Artikel in der EJU zeigt [15]. Später lag der primäre Fokus mehrerer Studien auf der Kombination von Elastografie und konventionellem B-Mode-Ultraschall und diese zeigten weitgehend überzeugende Resultate $[11,16]$. Dementsprechend wurde in der neuesten Auflage des BI-RADS-Klassifizierungssystems die Ultraschall-Elastografie, wahlweise SE oder SWE, als Zusatzmodalität zur Beurteilung des Malignitätsrisikos aufgenommen [17].

In jüngster Zeit liegt der Schwerpunkt der Diagnostik von Mammakarzinomen mittels Elastografie auf der Bewertung der schwierigen BI-RADS-Klassifikationen mit mittlerem Risiko, nämlich BI-RADS 3 und 4a, wie bei einer kürzlich hier in der EJU veröf- 
fentlichten Arbeit [10]. In dieser Studie mit mehr als 1000 Mammakarzinomen wurde die Prä-Test-POD („probability of disease“) von Brustkrebs von 1,3\% für BI-RADS 3 auf eine Post-Test-POD von 29,8\% nach Berechnung der Strainratio verbessert. Ebenso wurde für BI-RADS 4 die Prä-Test-POD von Brustkrebs von $8,5 \%$ auf eine Post-Test-POD von $48,7 \%$ durch die Strainratio erhöht. In einer weiteren Studie, die sowohl die Strain- als auch die Scherwellen-Bildgebung verwendete, wurden 290 von 494 BI-RADS 4a Tumore auf BI-RADS 3 heruntergestuft, wobei nur eine maligne Läsion fälschlicherweise degradiert wurde [18]. In einer Studie, in der Frauen mit BI-RADS-Klassifikation 4a aufgrund der bekannten Brustkrebs-Risikofaktoren in zwei Gruppen (durchschnittliches Risiko und Hochrisiko) unterteilt wurden, wurden Frauen mit durchschnittlichem Risiko mittels Strain-Elastografie zusätzlich in solche mit weichen und nicht-weiche Läsionen unterteilt. Mit einer Malignitätsrate von 1,5\% in der Untergruppe mit weichen Läsionen ist diese Häufigkeit vergleichbar mit BI-RADS 3 Tumoren [19]. In einer weiteren großen Studie wurde die SWE sowohl zum „Upgrade“ von BI-RADS 3 als auch zur Herabstufung von BI-RADS 4a Tumoren verwendet, wodurch die Gesamtspezifität der Untersuchung verbessert wurde, ohne entsprechende Einbußen bei der Sensitivität [11]. Sowohl die EFSUMB- als auch die WFUMB-Leitlinien zur Ultraschall-Elastografie sprechen für diese als Ergänzung zur B-Mode-Untersuchung bei Mammakarzinomen und stimmen zu, dass die Elastografie eingesetzt werden kann, um steife Läsionen der BI-RADS 3 Kategorie für eine umgehende Biopsie höher zu stufen $[1,20]$.

In jüngster Zeit lag der Schwerpunkt mehrerer Forschungspublikationen auf der Bewertung des Ansprechens von Mammakarzinomen auf neoadjuvante Chemotherapie durch Ultraschall-Elastografie. In einem kürzlich in der EJU erschienenen Artikel wurde gezeigt, dass die 3D-Scherwellen-Elastografie eine praktikable bildgebende Methode zur Bewertung volumetrischer Veränderungen von Mamma-Karzinomen nach neoadjuvanter Chemotherapie ist. Darüber hinaus konnte eine im vergangenen Jahr veröffentlichte Arbeit zeigen, dass die konventionelle 2D-Scherwellen-Elastografie die pathologische Komplettremission nach neoadjuvanter Chemotherapie nach drei Behandlungszyklen besser vorhersagen kann, als konventioneller US und MRT zusammen [21, 22]. Diese Ergebnisse wurden durch Publikationen untermauert, die aufzeigen, dass die Strain-Elastografie nach zwei Wochen Chemotherapie eine pathologische Komplettremission vorhersagen kann und dass die Ergebnisse durch die Kombination von Elastografie mit kontrastverstärktem Ultraschall weiter verbessert werden können [23-25].

Die 3D-SWE wurde auch für die Beurteilung der Tumorgröße bei Brustkrebs in einer aktuellen Studie verwendet [26]. Im Vergleich zur 2D-SWE, Strain-Elastografie und zum B-Mode Ultraschall war die konventionelle B-Mode Bildgebung überlegen, obwohl 3D-SWE in der Untergruppe mit invasiv-duktalem Karzinom genauer war als 2D-SWE und SE.

Um elastografische Untersuchungen zu automatisieren wurden computergestützte Methoden bewertet und eine Studie mit Texturanalyse bei SWE zur Tumorklassifizierung zeigte Verbesserungen der Spezifität, Sensitivität und Genauigkeit im Vergleich zur herkömmlichen SWE-Auswertung [27]. In einer weiteren Studie zur Auswertung der Echtzeit-Strain-Elastografie (SE) wurde ein Verfahren zur Berechnung von vier SE-Merkmalen entwickelt, die die Spezifität von 54,5\% auf 95,2\% verbessern, wenn der B-Mode US mit der computergestützten SE kombiniert wurde [28].

In diesen Jahren hat die künstliche Intelligenz (KI) in der Medizin viel Aufmerksamkeit erlangt und die Mamma-Bildgebung ist einer ihrer Schwerpunkte [29]. Für die Segmentierung, ein entscheidender Schritt für die Leistungsfähigkeit der KI, wurde der Einsatz der Elastografie neu vorgeschlagen. Ein Algorithmus zur automatischen Segmentierung von Brusttumoren wurde durch Bildfusion von B-Modus, Power-Doppler- und SWE-Elastografie vorgeschlagen [30]. In einer retrospektiven Studie wurden SWEund B-Mode-Bilder segmentiert, analysiert und die Daten wurden in einen Lern- und Klassifizierungs-Algorithmus eingegeben. Die Studie zeigte eine Sensitivität von $97,8 \%$, eine Spezifität von 94,1 \% und eine Genauigkeit von 95,6\% und könnte somit möglicherweise ein nicht-invasives diagnostisches Verfahren werden, um unnötige Biopsien zu vermeiden [27].

Die Elastografie ist zu einem nützlichen diagnostischen Hilfsmittel der Mamma-Bildgebung und Tumorbewertung geworden und wird immer mehr zu einem integralen Bestandteil der Brustdiagnose. Mit der Einführung der 3D-Elastografie sowie den computergestützten Methoden und der für die Elastografie entwickelten $\mathrm{KI}$ werden sich neue Möglichkeiten ergeben, die den Einsatz dieser leistungsstarken Ultraschalltechnik weiter verbessern.

\section{References}

[1] Săftoiu A et al. The EFSUMB Guidelines and Recommendations for the Clinical Practice of Elastography in Non-Hepatic Applications: Update 2018. Ultraschall der Medizin - Eur J Ultrasound 2019; 40: 425-453

[2] Dietrich C et al. EFSUMB Guidelines and Recommendations on the Clinical Use of Liver Ultrasound Elastography, Update 2017 (Long Version). Ultraschall der Medizin - Eur J Ultrasound 2017; 38: e48

[3] Barr RG et al. WFUMB Guidelines and Recommendations on the Clinical Use of Ultrasound Elastography: Part 5. Prostate. Ultrasound Med Biol 2017; 43: 27-48

[4] Barr RG et al. WFUMB guidelines and recommendations for clinical use of ultrasound elastography: Part 2: breast. Ultrasound Med Biol 2015; 41: $1148-1160$

[5] Cosgrove D et al. WFUMB Guidelines and Recommendations on the Clinical Use of Ultrasound Elastography: Part 4. Thyroid. Ultrasound Med Biol 2017; 43: 4-26

[6] Shiina T et al. WFUMB Guidelines and Recommendations for Clinical Use of Ultrasound Elastography: Part 1: Basic Principles and Terminology. Ultrasound Med Biol 2015; 41: 1126-1147

[7] Bamber J et al. EFSUMB Guidelines and Recommendations on the Clinical Use of Ultrasound Elastography. Part 1: Basic Principles and Technology. Ultraschall der Medizin - Eur J Ultrasound 2013; 34: 169-184

[8] Itoh A et al. Breast Disease: Clinical Application of US Elastography for Diagnosis. Radiology 2006; 239: 341-350

[9] Carlsen J et al. Ultrasound Elastography in Breast Cancer Diagnosis. Ultraschall in Med 2015; 36: 550-562; quiz 563-565

[10] Zhao XB et al. Strain Elastography: A Valuable Additional Method to BI-RADS? Ultraschall der Medizin - Eur J Ultrasound 2018; 39: 526-534

[11] Berg WA et al. Shear-wave Elastography Improves the Specificity of Breast US: The BE1 Multinational Study of 939 Masses. Radiology 2012; 262: 435-449 
[12] Tanter M et al. Quantitative Assessment of Breast Lesion Viscoelasticity: Initial Clinical Results Using Supersonic Shear Imaging. Ultrasound Med Biol 2008; 34: 1373-1386

[13] Evans A et al. Quantitative shear wave ultrasound elastography: initial experience in solid breast masses. Breast Cancer Res 2010; 12: R104

[14] Zhi H et al. Semi-quantitating Stiffness of Breast Solid Lesions in Ultrasonic Elastography. Acad Radiol 2018; 15: 1347-1353

[15] Dória MT, Jales RM, Conz L et al. Diagnostic accuracy of shear wave elastography - Virtual touch TM imaging quantification in the evaluation of breast masses: Impact on ultrasonography's specificity and its ultimate clinical benefit. Eur J Radiol 2019; 113: 74-80

[16] Chang JM et al. Comparison of Shear-Wave and Strain Ultrasound Elastography in the Differentiation of Benign and Malignant Breast Lesions. Am J Roentgenol 2013; 201: W347-W356

[17] Mendelson EB, Böhm-Vélez M, Berg WA et al. ACR BI-RADS® Ultrasound. In: ACR BI-RADS ${ }^{\circ}$ Atlas, Breast Imaging Reporting and Data System Reston, VA: Am Coll Radiol. 2013

[18] Zheng $X$ et al. Combination of different types of elastography in downgrading ultrasound Breast Imaging-Reporting and Data System category 4a breast lesions. Breast Cancer Res Treat 2019; 174: 423-432

[19] Koh J et al. Role of elastography for downgrading BI-RADS category $4 a$ breast lesions according to risk factors. Acta radiol 2019; 60: 278-285

[20] Barr RG et al. WFUMB Guidelines and Recommendations for Clinical Use of Ultrasound Elastography: Part 2: Breast. Ultrasound Med Biol 2015; 41: 1148-1160

[21] Athanasiou A et al. Feasibility of Imaging and Treatment Monitoring of Breast Lesions with Three-Dimensional Shear Wave Elastography. Ultraschall der Medizin 2017; 38: 51-59
[22] Evans A et al. Prediction of Pathological Complete Response to Neoadjuvant Chemotherapy for Primary Breast Cancer Comparing Interim Ultrasound, Shear Wave Elastography and MRI. Ultraschall der Medizin Eur J Ultrasound 2018; 39: 422-431

[23] Fernandes J et al. Monitoring Breast Cancer Response to Neoadjuvant Chemotherapy Using Ultrasound Strain Elastography. Transl Oncol 2019; 12: 1177-1184

[24] Fang C, Yang TWYZJXW. Value of tissue elastography in the prediction of efficacy of neoadjuvant chemotherapy in breast cancer. J BUON 2019; 24: 555-559

[25] Wang B et al. Evaluation of the response of breast cancer patients to neoadjuvant chemotherapy by combined contrast-enhanced ultrasonography and ultrasound elastography. Exp Ther Med 2019; 17: 36553663

[26] Farrokh A, Maass N, Treu L et al. Accuracy of tumor size measurement: comparison of B-mode ultrasound, strain elastography, and 2D and 3D shear wave elastography with histopathological lesion size. Acta radiol 2019; 60: 451-458

[27] Zhang Q, Xiao Y, Chen S et al. Quantification of Elastic Heterogeneity Using Contourlet-Based Texture Analysis in Shear-Wave Elastography for Breast Tumor Classification. Ultrasound Med Biol 2015; 41: 588-600

[28] Xiao Y et al. Ultrasound Strain Elastography for Breast Lesions: Computer-Aided Evaluation With Quantifiable Elastographic Features. J Ultrasound Med 2017; 36: 1089-1100

[29] Pehrson LM, Lauridsen C, Nielsen MB. Machine learning and deep learning applied in ultrasound. Ultraschall in Med 2018; 39: 379-381

[30] Keatmanee C, Chaumrattanakul U, Kotani K et al. Initialization of active contours for segmentation of breast cancer via fusion of ultrasound, Doppler, and elasticity images. Ultrasonics 2019; 94: 438-453 